\title{
マイクロ波による鉄道通信システムにおける伝搬特性
}

\begin{tabular}{|c|c|c|c|c|c|c|}
\hline 正 & 員 & 服 & 部 & 鉄 & 範 & (東北大) \\
\hline & 員 & 阿 & 部 & 紘 & \pm & (秋田県立) \\
\hline & 員 & 土 & & 孝 & 泰 & （東北大） \\
\hline & 員 & 阿 & 部 & 健 & & （東北大） \\
\hline
\end{tabular}

\section{Study on Propagation Characteristics in Railway Communication Systems Using the Microwave Band Radio}

\begin{abstract}
Recently, the utilization of radio equipments along railways have been advanced rapidly in Japan. The importance of these radio systems rise in train control, information services and other communication systems. But the current frequency band width in UHF band assigned to Japanese railway companies is narrow to satisfy future various requirements for railway works and customer services. In this paper, we first present a construction of a next generation radio communication system using the microwave band radio between running trains and ground radio base station, as the system which can cope with the increase of the communication traffic volume in the railway communication. Secondly, we study the propagation characteristics on radio links to introduce this communication system into actual conventional lines. Concretely, we consider that the typical railway environments are distinguished to several types on analyses by complication of environments along a railway track. For each type, we calculate the propagation characteristics on a proper model. Also, we examine influences of rain which have an important effect on circuit quality. Computer simulation indicates that these analyses are effective to rationalize this communication system using the microwave band radio.
\end{abstract}

$$
\text { キーワード：鉄道沿線環境，列車無線通信システム，マイクロ波伝搬特性，レイトレーシング，降雨隇衰 }
$$

\section{1.まえがき}

近年，鉄道軌道沿線に沿った各種無線設備の利用は， 急速に進んでいる。列車無線に代表される通話系無線に 加之, 列車接近鳘報装置や進路構成用無線等の非通話系 無線への応用が進み，将来的には列車位置情報の伝送や マルチメディア車内情報サービスあるいは沿線監視等へ の応用も期待されている。しかしながら、これら無線設 備のキャリア周波数について見た場合，現在，日本の鉄 道会社に割り当てられている周波数带域幅は，将来の鉄 道業務や旅客サービスに関する需要の増大を考虑した場 合，容量的に十分とは言えない。例えば，ある代表的な 在来線のアナログ式列車無線システムでは，U H F 帯で の $100 \mathrm{kHz}$ に 8 チャンネルが収容されており，1線区 あたり $12.5 \mathrm{kHz}$ の带域幅となって扔り，将来の多様な 無線による情報伝送を考えた場合，従来よりも効率的な 周波数利用が課題となる。

一方，鉄道以外の陸上移動体通信における周波数割り
当ての動向をみると，IMT2000に代表されるように 準マイクロ波帯の利用が促進されつつある。道路交通に おいてはI T S が多様な機能を有する新たな輸送システ ムとして研究されている。またヨーロッパの鉄道で推進 されているMORANEプロジェクトの中の G SM-R システム(1)では, 音声·文字・データ通信を对象とした 対列車無線通信を想定している。しかしながらこのシ ステムを国内における大容量伝送が可能な，次世代の鉄 道通信システムとして用いることは困難である。

このような，現在の鉄道通信を取り巻く状況より，今 後の鉄道移動体通信におけるキャリア周波数の利用動向 について考察すると，次の $2 つ の$ 可能性が考えられる。 一方は現在, 利用されているU H F 帯をデジタル・ナロ 一化する方法であり（方式 1)，他方は現在より広带域 が確保可能な, 高い周波数带を用いる方法である(方式 2 )。特に大容量の情報伝送に適した通信システムを想 定した場合，マイクロ波帯以上の高い周波数带を用いる 必要がある。 
これら両方式にはそれぞれ次の利点がある。

方式 1

・アナログで回線設計の実績がある。

・周波数带域について認可済み。

・伝搬距離がマイクロ波等と比較して長距蜼。

方式 2

・通信トラフィックが大きな区間での大容量通信。

·基地局設備の小型化。

・指向性の強い電波放射が可能。

適用区間の通信トラフィック量によって而方式の使い 分けも考えられる。本稿では首都圈および主要路線での 将来的なトラフィックの增大に対処するために, 大容量 通信が可能な方式 2 について電波伝搬特性に関する検討 を行う。なお適用線区は、様々な沿線環境に適用可能と するため, 在来線とする。最初に, 列車と地上設備間の 通信システムである列車無線システムに本方式を採用し 使用周波数としてマイクロ波を用いた場合のシステム構 成についてその概念を示した後, 在来線沿線環境におけ るマイクロ波伝搬特性の理論的な取扱いについて，モデ リング手法の提案および解析方法の選定を行う。次に具 体的な沿線環境モデルでの数值解析例を受信レベル变動 と降雨隇衰量について示す。

これらにより，在来線沿線環境における，マイクロ波 伝搬特性の理論的な取扱い手法を明らかにし，また，シ ステム設計時に，本手法が適用可能であることを示す。

\section{2.マイクロ波による列車無線通信システム}

従来のUH F 帯による列車無線通信システムに代えて 大容量情報伝送が可能なマイクロ波をキャリア周波数と して採用した在来線用列車無線通信システムの構成を図 1 に示す。制御装置から無線基地局までの通信システム にはサブキャリア多重・光伝送方式(2)(3)を採用する。

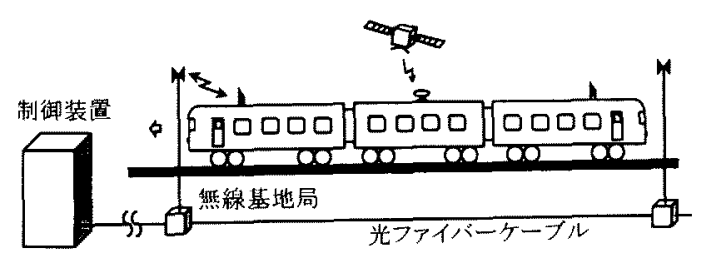

a) SCM 光任送方式

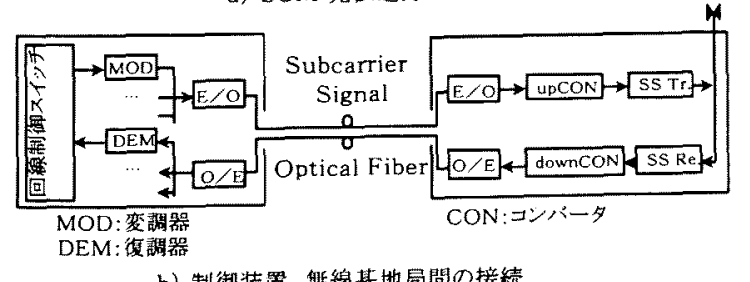

b）制御装置、然楾基地局間の接続

図1列車通信システムの構成

Fig.1. Conceptual diagram of a railway communication system

本システムの概要は次の通りである(4)。
（1）具体的な無線周波数帯は，社会的な要因も含め て決定されるため，限定するのが難しい面がある。表 1 に, UHF 帯からミリ波帯までの幾つかの無線周波数带 の特徵を示す。本稿では, 国内の周波数割り当ての状況 より広帯域が確保可能と考えられるマイクロ波帯以上の 中で，七ル半径を大きくして基地局数を少なく抑えるこ とと, 基地局, 移動局のアンテナ設置の容易性を考慮し て，25GHzをキャリア周波数として選択する。

\section{表 1 無線周波数帯の特徽}

Table 1. Features of radio frequency

\begin{tabular}{|c|c|c|c|c|c|}
\hline 項目 & $\begin{array}{l}\text { UHF带 } \\
400 \mathrm{MHz}\end{array}$ & $\begin{array}{l}\text { UHF带 } \\
2 \mathrm{GHz}\end{array}$ & \begin{tabular}{|l|} 
マイタ口波带 \\
$8.45 \mathrm{GHz}$
\end{tabular} & $\begin{array}{l}\text { マイクロ波带 } \\
25 \mathrm{GHz}\end{array}$ & $\begin{array}{l}\text { ミリ波带 } \\
45 \mathrm{GHz}\end{array}$ \\
\hline $\begin{array}{l}\text { 带域楅 }(\mathrm{MHz}) \\
\text { (100MHz地上，国内) }\end{array}$ & - & - & 100 & 1000 & 3500 \\
\hline $\begin{array}{r}\text { セル半径の殆 } \\
(\mathrm{km})\end{array}$ & 15 & 3 & 0.75 & 0.25 & 0.15 \\
\hline 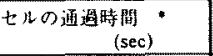 & 675 & 135 & 34 & 11 & 7 \\
\hline $\begin{array}{c}\text { 七ル端での空間損矢 } \\
\text { (dB) }\end{array}$ & 108.0 & 108.0 & 108.5 & 108.4 & 109 \\
\hline 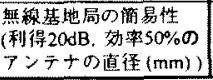 & - & 675.2 & 159.8 & 54.0 & 30.0 \\
\hline
\end{tabular}

・列車速度は $160 \mathrm{~km} / \mathrm{h}$ とする。

（2）制御装置は，20３0 km 每に設置され，軌道沿 線 $1.0 \sim 1.1 \mathrm{~km}$ 毎に設置された無線基地局との間を光つ アイバーで接続する構成とする。但し，この基地局間隔 は沿線構造物による無線伝搬路のマルチパス化と高周波 における降雨減衰の影響を考慮し，場所每に個別に設計 する必要がある。なお, 光ファイバー網については既に 鉄道軌道沿線での敷設が進んでいるため既設の回線を利 用できる可能性が高い。

（3）無線りンクは軌道に沿って配置された、マイク ロセル構成(5)とする。スペタトラム拡散方式の採用によ り全セルにおいて同一キャリア周波数を使用する。また 無楾基地局には回線制御装置は置かず，E/O变換器， 周波数变換器, 增幅器のみとなるため, 小型化, 低コス トの基地局設計が期待できる。

(4) 送受信アンテナには $20 \mathrm{~dB}$ 程度の利得と $30 \mathrm{~dB}$ 以上の F/B 比を有する指向性アンテナ(電磁ホーン)を採 用する。移動局である列車には, 約 $200 \mathrm{~m}$ の在来線列 車一編成の前頭部および後尾部の屋根上にアンテナを設 け，800～900m 程度の近距離通信を行う。沿線の無線 基地局のアンテナは，鉄柱やコンクリート柱等の沿線構 造物に固定し, 軌道方向へ約 10 度傾けて, 車上局アン テナと対向に設置する。

以下，本システムの無線回線設計を行う上において必 要な鉄道沿線におけるマイク口波伝搬特性に関して，解 析手法の検討を行う。

\section{3.マイクロ波伝搬特性}

く3・1>伝搬特性に影䇾を及ぼす要因鉄道沿線 環境を，電波伝般特性の観点から見た場合，大地や切り 
通し，側壁，高架橋，トンネル，駅舎，対向列車等の鉄 道沿線構造物により伝搬環境は影響を受け，特にマイタ 口波帯以上の伝搬においては，沿線基地局と移動体であ る列車との間の伝搬路は見通し内伝搬ではあるが，反 射・散乱現象により，マルチパスとなりやすい。鉄道の 場合, 基地局は軌道に沿って線状に配置され, 列車は周 期的に基地局脇に近接して走行し，その経路は常に一定 である点が自動車の走行環境と異なる。また，一般に $10 \mathrm{GHz}$ 以上の伝搬に扔いては降雨による電波の減衰が 生じ, 激しい降雨時には回線断が発生する。

本章ではまず、マルチパス環境を含めた鉄道沿線環境 における受信レベルの低下・変動を理論的に算定するこ とを目的として、鉄道沿線環境の分類を行い，幾つかの 環境に扮ける数值解析例を示す。次に，降雨量の增大が 無線回線に及ぼす影響について, 降雨減衰量により定量 的な評価を行う。

$<3 \cdot 2\rangle$ 鉄道沿線環境の分類伝搬特性を理論的 に解析することを前提に, 在来線の沿線環境の分類を行 う。鉄道沿線における伝搬は, 受信レベルの累積分布が 仲上一ライス分布となることが見込まれるため，存在す る波としては直接波とマルチパスによる反射波成分が支 配的となる。また，鉄道沿線環境を複雑性から，表 2 の ように類型化することにより，環境と解析手法（波の考 慮法)とを対応付けることが可能となる。

\section{表 2 各領域における特性解析方法}

Table 2. Analyzing methods in each area

\begin{tabular}{|c|c|c|c|c|c|}
\hline & $\begin{array}{l}\text { 解析上の } \\
\text { 緗区種別 }\end{array}$ & 周辺箱造物 & 電化有無 & 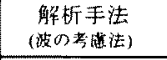 & $\begin{array}{r}\text { 考察すべきパス } \\
\text { (西㥪波除く) } \\
\end{array}$ \\
\hline \multirow{5}{*}{$\begin{array}{l}\text { 潟 } \\
\text { 中開 }\end{array}$} & \multirow{2}{*}{ 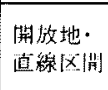 } & \multirow{2}{*}{ 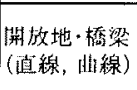 } & 非電化 & 2波干涉 & 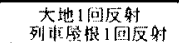 \\
\hline & & & 電化 & 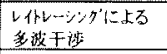 & 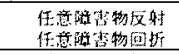 \\
\hline & \multirow[t]{2}{*}{ 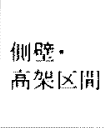 } & \multirow[t]{2}{*}{ 高架·側晊 } & 非垂化 & 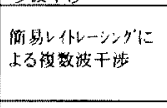 & 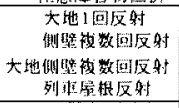 \\
\hline & & & 霆化 & \multirow{3}{*}{$\begin{array}{l}\text { レイレーシグによる } \\
\text { 多没干涉 }\end{array}$} & \multirow{3}{*}{ 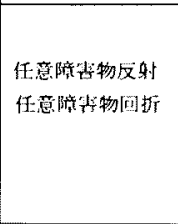 } \\
\hline & $\begin{array}{l}\text { 枋街地・ } \\
\text { 山间区消! }\end{array}$ & $\begin{array}{l}\text { 切通 } \\
\text { 浴楾ビル } \\
\text { 立体交差 } \\
\text { 見进外の幻配 }\end{array}$ & $\begin{array}{l}\text { 雀化- } \\
\text { 非浬化 }\end{array}$ & & \\
\hline 駅 & & & & & \\
\hline
\end{tabular}

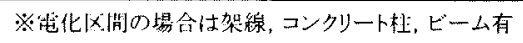

解析方法（波の考慮法）としては，2 波干涉, 簡易レ イトレーシング法による複数波干渉，レイトレーシング 法による多波干涉の三種類を用い，考察すべき領域に存 在する波の支配的要因により各方法を使い分けることに より，簡便で効率的なシミュレーションを行うことがで きる。設備的にはまず，駅中間（駅と駅の間の区間）と 駅構内とに分類し, 構内には比較的多くの構造物が存在 するため、レイトレーシング法による多波干涉を考慮す る。一方, 駅中間においては沿線環境により更に開放 地・直線区間，側壁·高架区間，市街地・山間区間と分 類した上で電化設備の有無を考慮し，上記三種類のいず
れかの方法を適用する。本稿では各方法における解析例 を示すため, 図2のように非電化の駅中間の 3 領域 Area1. 〜 Area3.を代表としてモデリングおよび数値解 析を行う。

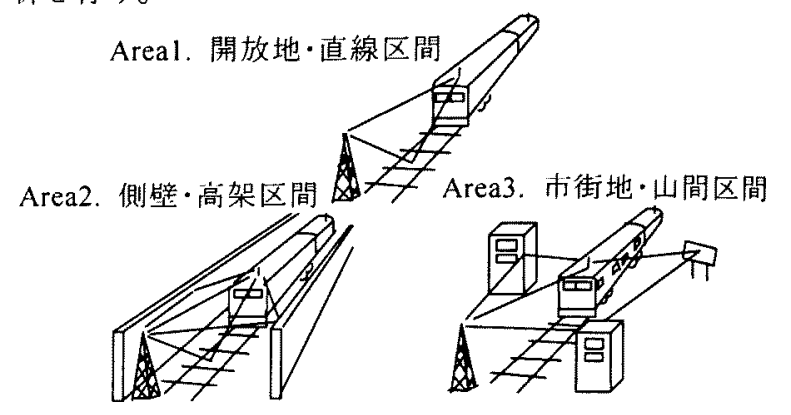

図 2 解析対象領域

Fig.2. Analyzed areas

\section{$\langle 3 \cdot 3\rangle$ 数值解析例 1 (開放地・直線区間)}

本領域に扔ける解析モデルを図 3 に示す。列車は上下 線で進行方向が変わるため，車上アンテナは，前頭部お よび後尾部の二ヶ所に設置する。また本稿では直接述べ ないが, 両アンテナ間にダイバーシチ受信方式を採用す ることで受信性能の向上が見込める(4)。なお前頭部アン テナは直接波拉よび大地反射波, 後尾部アンテナは, 直 接波拉よび列車屋根反射波の影暨が支配的である。图で 基地局アンテナ高を $\mathrm{Hb}$, 列車屋根高 $\mathrm{Hr}$, 列車アンテナ 高 $\mathrm{Ht}$, 列車長 $\mathrm{Lt}$, 列車アンテナの車両端加らの離隔を Laとする。

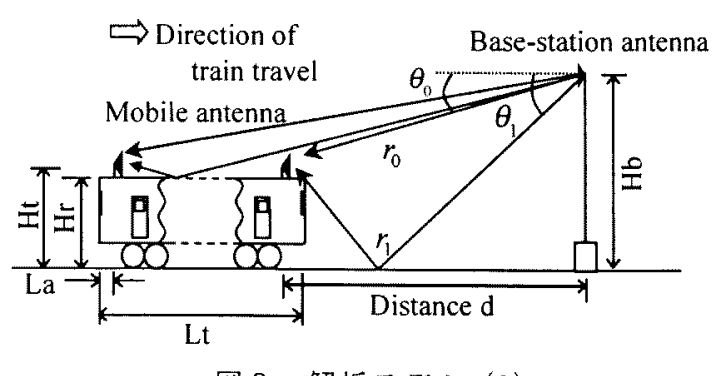

図 3 解析モデル (1)

Fig. 3. Analyzed model (1)

直接波による受信点での電界強度 $E_{\mathrm{D}}$ は次式となる。

$E_{D}=E_{0} \exp \left(-j k r_{0}\right) \times D_{T}\left(\theta_{0}\right) \cdot D_{R}\left(\theta_{0}\right)$

$E_{0}:$ 直接波の振幅, $r_{0}$ : 直接波の光路長

$\theta_{0}:$ アンテナ中心と直接波が成す角

$D_{\mathrm{T}}, D_{\mathrm{R}}$ : 送信局, 受信局の指向性関数

$E_{0}$ については次式で表される。

$$
E_{0}=\frac{4 \sqrt{30} \pi}{\lambda} \sqrt{P t \cdot G t \cdot L s}
$$


$P_{t}:$ 送信電力, $G_{t}:$ 送信アンテナ利得

$\lambda$ : 波長, $L_{s}$ : 基本伝搬損

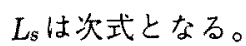

$$
L_{\mathrm{s}}=\left(\frac{\lambda}{4 \pi \pi_{0}}\right)^{2}
$$

また $k$ については，次式となる。

$$
k=\frac{2 \pi}{\lambda}
$$

指向性関数 $D_{\mathrm{T}}, D_{\mathrm{R}}$ は, 本解析では(5)式で表される。 ここで $x$ は $G_{t}$ と受信アンテナ利得 $G_{t}$ が $20 \mathrm{~dB} の と き ，$ $x=52$ となる。

$$
\begin{aligned}
10 \cdot \log D_{T, R}(\theta) & =10 \cdot \log \cos ^{x} \theta \quad\left(|\theta|<20^{\circ}\right) \\
& =32-20 \log \theta-G_{i, r}\left(|\theta| \geq 20^{\circ}\right)
\end{aligned}
$$

次に反射波の受信点での電界強度 $E_{\mathrm{R}}$ は,

$$
\begin{aligned}
E_{R}= & E_{0} \exp \left(-j k r_{0}\right) \\
& \times D_{T}\left(\theta_{1}\right) \cdot D_{R}\left(\theta_{1}\right) \cdot R \cdot \exp \left\{-j k\left(r_{1}-r_{0}\right)\right\} \\
r_{1} & : \text { 大地 } 1 \text { 回反射波の光路長 } \\
\theta_{1}: & \text { アンテナ中心と反射波が成す角 }
\end{aligned}
$$

$R$ :大地もしくは列車屋根の複素反射係数

式(1)と（6）を足し合わせることにより受信電界強度 $E$ は次式にて表される。

$$
\begin{aligned}
& E=E_{0} \exp \left(-j k r_{0}\right)\left[D_{0}+D_{1} \cdot R \cdot \exp \left\{-j k\left(r_{1}-r_{0}\right)\right\}\right] \\
& D_{0}=D_{T}\left(\theta_{0}\right) D_{R}\left(\theta_{0}\right), D_{1}=D_{T}\left(\theta_{1}\right) D_{R}\left(\theta_{1}\right)
\end{aligned}
$$

(7)式より，受信電界強度 $\mid E$ |は次式にて表される。

$$
|E|=E_{0} \sqrt{\left(D_{0}+D_{1} R \cos \delta\right)^{2}+\left(D_{1} R \sin \delta\right)^{2}}
$$

ここで, $\delta=k\left(r_{1}-r_{0}\right)$ とする。また，TM 波， TE 波に 対するフレネルの反射係数 $R$ は次式で与えられる(6)。

$$
\begin{aligned}
& R_{T M}=\frac{\varepsilon \cos \varphi-\sqrt{\varepsilon-\sin ^{2} \varphi}}{\varepsilon \cos \varphi+\sqrt{\varepsilon-\sin ^{2} \varphi}} \\
& R_{T E}=\frac{\cos \varphi-\sqrt{\varepsilon-\sin ^{2} \varphi}}{\cos \varphi+\sqrt{\varepsilon-\sin ^{2} \varphi}} \\
& \varepsilon=\varepsilon_{r}-\frac{j \sigma}{\omega \varepsilon_{0}} \\
& \varphi \text { : 入射角, } \sigma \text { : 導電率, } \varepsilon_{\mathrm{r}} \text { : 比誘電率 } \\
& \varepsilon_{0} \text { : 真空誘電率, } \omega \text { : 角周波数 }
\end{aligned}
$$

結局，直接波と大地反射波もしくは屋根反射波の合成 波による電界强度は $(9)$ 式で与えられる。

ここで、鉄道車両の場合、車両自体の形状と設置され るアンテナ位置，送受信位置によって，直接波，大地反 射波，屋根反射波の 3 波の中で考慮す心゙き波が変わるた
め，車而自体が伝搬上の支障物になり得るとの観点から 波の有無を判定する必要がある。本稿では, 鉄道車両に 関する諸寸法を図4のように定義し，車上アンテナにお いて, 車体による無線伝播路の遮蔽により, 波が存在し ない場合の条件を前頭部アンテナの例について示す。

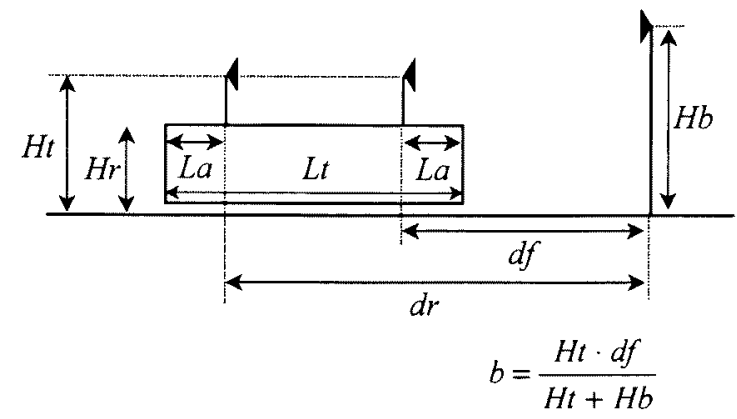

困 4 列車寸法の定義

Fig. 4. The definition of the train dimension

$H b>H r$ の場合, 波の非存在条件は次の通りである。 $\frac{H t(b-L a)}{b}<H r$ : 大地反射波が無い。 $\frac{(H b-H r) \cdot d f}{(H t-H r)+(H b-H r)}<d f-L a$; 屋根反射波が無い。

$H b \leq H r$ の場合，波の非存在条件は次の通りである。 $\frac{H t(b-L a)}{b}<H r$ : 大地反射波が無い。

屋根反射波は常に無い。

次に，図 3 のモデルにて(9)式により，相対受信レべ ルの算定を行った結果を図 5 に示す。計算時の諎条件は 表 3 の通りである。図中, 奏線は前頭部アンテナの相対 受信レベル，破線が後尾部アンテナの相对受信レベルで ある。横軸は基地局間隔 $\mathrm{L}(=1.0 \mathrm{~km})$ と列車運行速度 $\vee に$ よって規格化された時間軸である。例えば，前頭部アン テナは時間1あるいは 2 のとに基地局に最接近する。 送受信距離が長い箇所では，前頭部の2 波干渉によるレ ベルの落ち込みを後尾部のレベルにより補償することが 可能である。

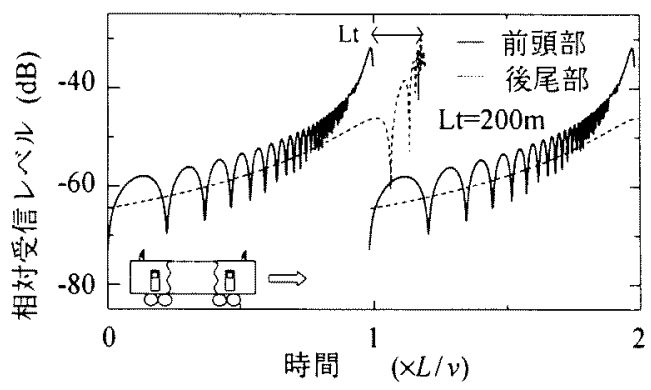

図 5 伝搬特性 (1-1)

Fig. 5. The propagation characteristics (1-1) 
表 3 計算時の諸条件（1）

Table 3. Analyzing conditions (1)

\begin{tabular}{|c|c|c|c|}
\hline 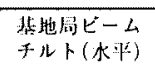 & $10 \mathrm{deg}$ & 列車高 $\mathrm{Ht}$ & $3.5 \mathrm{~m}$ \\
\hline 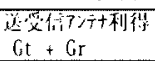 & $40 \mathrm{~dB}$ & 列車高 $\mathrm{Hr}$ & $3.2 \mathrm{~m}$ \\
\hline 周波数 f & $25 \mathrm{GHz}$ & 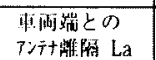 & $1.0 \mathrm{~m}$ \\
\hline 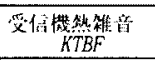 & $-90 \mathrm{~dB}$ & 大地物性值 & 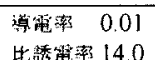 \\
\hline 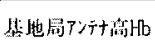 & $6.0 \mathrm{~m}$ & & \\
\hline 編成長 Lt & $200 \mathrm{~m}$ & 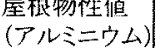 & 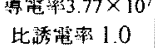 \\
\hline
\end{tabular}

次に，車上後尾部アンテナ高を変化させた際の相対受 信レベルの算定結果を図 6 に示す。

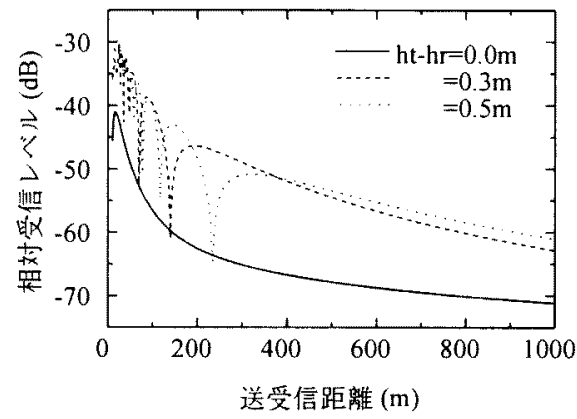

図 6 伝搬特性 $(1-2)$

Fig. 6. The propagation characteristics (1-2)

車上アンテナが高い程，屋根反射によるフェージング が発生しやすい様子が観測される。実際のシステム設計 時にはこのように構成装置の各種定数を变えてシミュレ ーションを行う必要がある。

\section{$\langle 3 \cdot 4\rangle$ 数值解析例 2 (側壁・高架区間)}

本領域における解析モデル(7)を図７に示す。列車はコ ンクリート製側壁間を進行し, 両側からの反射波の影響 を受ける。本モデルでは, それら素波の経路については 簡易にレイトレーシングを行うことが可能である。本稿 では，前頭部アンテナにおける受信レベル算定を行う。

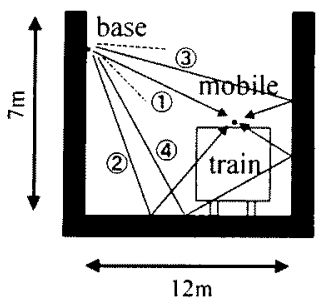

Cross view

(1) 青接波,

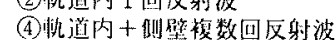

図 7 解析モデル (2)

Fig.7. Analyzed model (2)

任意反射波による電界強度 $E_{\mathrm{R}}$ は，次式で表される。

$$
E_{R}=E_{0} \cdot D_{r}\left(\theta_{T}\right) \cdot D_{R}\left(\theta_{R}\right) \cdot \exp (-j k r) \prod_{j=1}^{N} R_{j}
$$

$\theta \mathrm{T}$ ：送信アンテナ中心と最初の反射点との成す角 $\theta_{\mathrm{R}}$ : 受信アンテナ中心と最後の反射点との成す角 $R_{\mathrm{j}}$ : 各反射点 $\mathrm{j} に$ に打けるフレネルの複素反射係数 $r:$ 素波の行路長, $N$ : 反射回数

よって, 受信電界強度 $E$ は次式にて表される。

$$
\begin{aligned}
& E=\sum_{i=1}^{M}\left\{E_{0} \cdot D_{i} \cdot \exp \left(-j k r_{i}\right) \prod_{j=1}^{N} R_{j}\right\} \\
& D=D_{i}\left(\theta_{T}\right) \cdot D_{R}\left(\theta_{R}\right) \\
& M: \text { 考慮する素波 } i \text { の個数 }
\end{aligned}
$$

図 7 のデルにて(14)式により，受信レベルの算定を 行った結果を図 8 の実線にて示す。

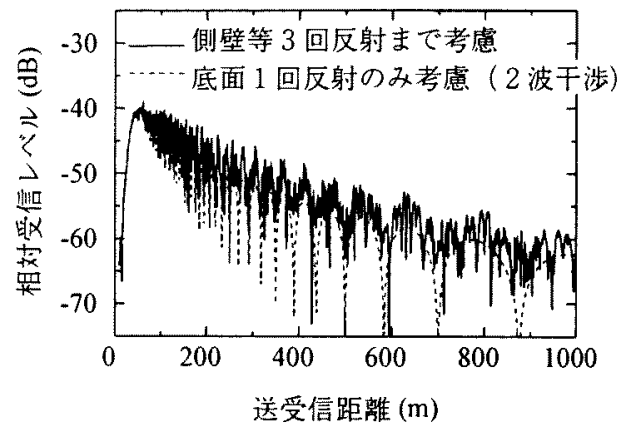

図 8 伝搬特性（2）

Fig. 8. The propagation characteristics (2)

図より特に送受信距離が長い位置において, 複数反射 波を考虑した影響が現れる様子が観測される。

また, 計算時の諸条件で表 3 と異なる部分は表 4 の通 りである。

表 4 計算時の諸条件（2）

Table 4. Analyzing conditions (2)

\begin{tabular}{|c|c|c|}
\hline \multicolumn{2}{|c|}{ 基地局ビームチルト(水平) } & $10 \mathrm{deg}$ \\
\hline \multirow{2}{*}{$\begin{array}{c}\text { コンクリート } \\
\text { 物性值 }\end{array}$} & 毞電率 & 6.76 \\
\cline { 2 - 3 } & 比誘電率 & 0.0023 \\
\hline
\end{tabular}

$\langle 3 \cdot 5\rangle$ 数值解析例 3（市街地・山間区間）

本領域における解析モデルを図 9 に示す。列車は立体 交差手前 $300 \mathrm{~m}$ の無線基地局脇より立体交差(軌道両側は コンクリート製，上部は鋼鉄製 (導電率 $1.029 \times 10^{7}$, 比 誘電率 1.0)) 人進入し, 反対方向へ抜ける。素波の経路 探索, すなわちレイトレーシングが複雑となる点が数值 解析例 2 と異なる。但し，本モデルでは常に送受信間の 見通しは保たれていることとして前頭部アンテナにおけ る相対受信レベルの算定を行う。なお，受信電界強度の 基本式には(14)式を用いる。 


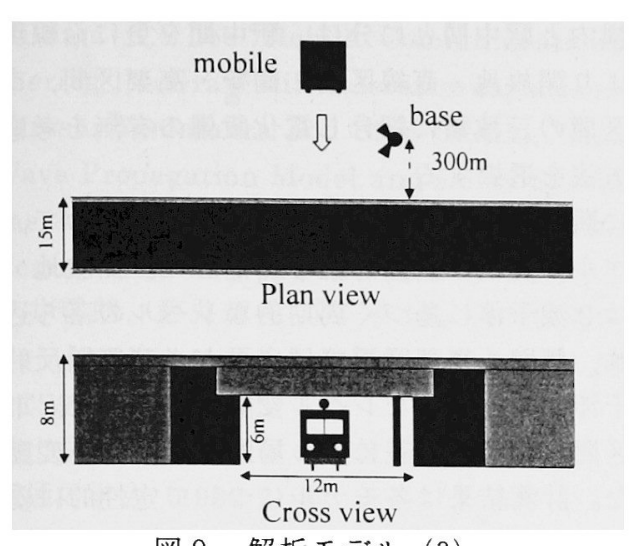

図 9 解析モデル (3)

Fig. 9. Analyzed model (3)

レイトレーシングの方法には，イメージング法 ${ }^{(8)}$ を採 用し，考察領域中の，経路が存在する可能性のある全て の面に対し経路探索を行う。なお，イメージング法で得 られた素波の中から有効な素波を検出するには素波の存 在判定を行う必要がある。その際，次の 3 プロセスによ り存在判定を行い。残った有効な素波に対して(14)式を 適用する。

（1）反射点を含む面を素波(直線)が横切るか。

（2）素波が面を横切る際に表面から入射しているか。

(3) 反射点間に直接波が存在するか。

図 10 に，相対受信レベルの算定結果を示す。送受信 間の見通しが保たれているため，全体としては大地反射 が支配的となるが. $380 \mathrm{~m}$ および $560 \mathrm{~m}$ 付近にて立体交差 の影響によるレベル変動が算定されている。

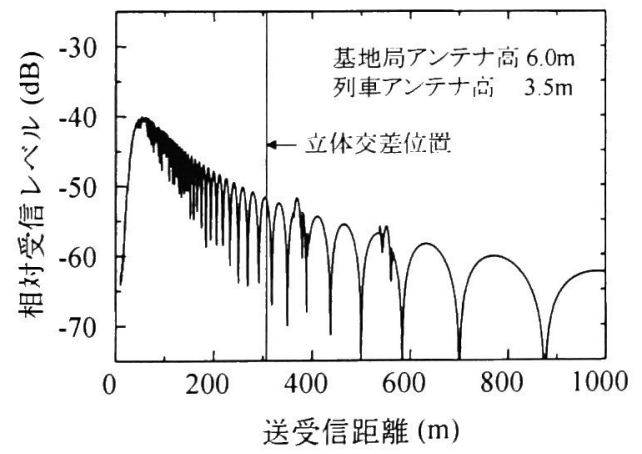

図 10 伝搬特性（3）

Fig. 10. The propagation characteristics (3)

〈3 $6>$ 降雨量と運転規制鉄道沿線のトンネ ル・地下部以外の領域，いわゆる明かり区間でのマイク 口波伝搬においては，降雨量の増大により伝搬特性が変 動するため，回線設計過程においてその影響を考慮する 必要がある。本稿では, 降雨による伝搬特性の変化を算 定し、システム設計時に適用可能な手法を示す。

最初に，考察に用いる最大時雨量の決定にあたり，列 車運行上の運転規制について整理する。雨量計が発令基
準值に達すると，運転速度制限あるいは運転見合わせと いった措置が講じられるため,この近傍で最大時雨量を 決定できる。但し発令基準值は，区間毎の耐降雨実績や 災害記録に基づいて統計的に求めており，統一的な值が 無いため, 最大基準値の調査を行った。その結果, 関 東 東北地域の雨量規制対象箇所では, 耐降雨性が良い 䇢所でも, 時雨量が $70 \mathrm{~mm} /$ hour を超えて運行する䇢所 は見当たらない。但し規制発令後, 駅中間にて知得した 列車では一定時間, 回線を確保する必要があるため, 本 解析では約 $25 \%$ のマージンを見込み, 最大 $90 \mathrm{~mm} / \mathrm{hour}$ で評価する。また，区間により規制基準が時雨量と連続 雨量の組合せで決まる場合があるが，減衰には短時間の 集中降雨が影響するため，時雨量のみで考察を行う。

$<37>$ 降雨減衰量一般に降雨減衰量は, 確率密 度分布関数として求められる。本稿では ITU-R の推定 法(9)を採用する。なお, 実験式である本方法の基礎デー 夕は主にヨーロッパではあるが、日本のデー夕も含まれ る。

一様に降雨があるとしたときの降雨減衰量 $Z_{0}(\mathrm{~dB})$ は, 次式で近似される。

$$
\begin{aligned}
& Z_{0}=\gamma \cdot \ell \\
& \gamma=K \cdot I^{n} \\
& \gamma: \text { 単位 } \mathrm{km} \text { あたりの減衰量 }(\mathrm{dB} / \mathrm{km}) \\
& I: \text { 降雨強度 }(\mathrm{mm} / \mathrm{min}), K, n: \text { 定数 }
\end{aligned}
$$

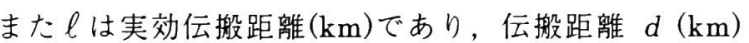
を用いて次式で表される。

$$
\ell=\frac{d}{1+\frac{d}{35 \exp (-0.015 I)}}
$$

数值解析例 1 の後尾部アンテナ高 $0.3 \mathrm{~m}$ 時の相対受信 レベル特性(図6)について，（16)式により降雨減衰量を 考慮した結果を図 11 に示す。なお, 周波数 $25 \mathrm{GHz}$ の とき， $\mathrm{K}=0.124 ， \mathrm{n}=1.061$ である。例えば 1 時間に $90 \mathrm{~mm}$ の降雨がある場合, $1 \mathrm{~km}$ 地点(サービスエリア 端を想定する。）においては晴天時より $13.2 \mathrm{~dB}$ の減衰 が生じる。

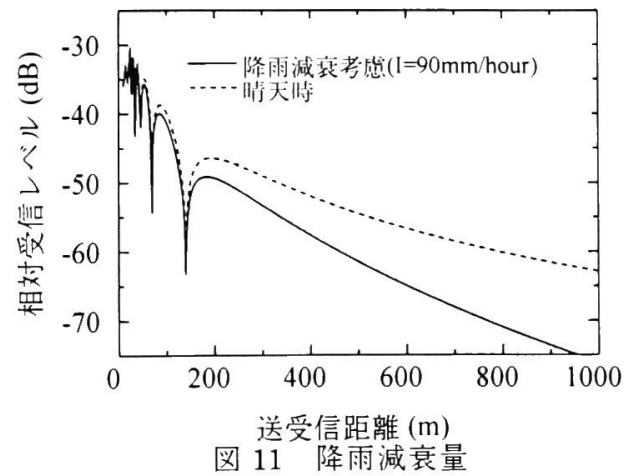

Fig.11. Attenuation caused by rainfall 
次に送受信系において許容減衰量 $\mathrm{Z} \mathrm{a}(\mathrm{dB})$ は次式にて 表される。(10)

$$
Z a=P_{t}+G_{t}+G_{r}-L_{s}-K T B F-C / N
$$

$K T B F$ : 熱雑音, $C / N$ : キャリア対雑音電力比

また，変調方式としてスペクトラム拡散方式を用いた とすると, 所要のビットエラーレートを満たす $C / N$ は 次式で表わされる。

$$
P_{c}=\frac{1}{2} e r f c \sqrt{C / N \cdot \frac{W}{R_{b}}}
$$

$W:$ 帯域幅 $(\mathrm{Hz})$

$R b:$ 伝送速度 $(\mathrm{bps})$

$P e:$ ビットエラーレート(BER)

よって許容減衰量と減衰量の差 $\left(Z \mathrm{a}-\mathrm{Z}_{0}\right)$ により, 送 受信系の耐降雨性に関する評価を行うことができる。

図 12 に降雨強度と送受信距離をパラメータとして送 受信系の耐降雨性(マージン)の傾向を示す。なお，送受 信性能としては, $P e=10^{-6} . W=50 \mathrm{MHz}, R b=384 \mathrm{kbps}$

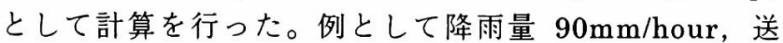
受信距離 $1 \mathrm{~km}$ 地点に打いては, $38.02 \mathrm{~dB}$ の耐降雨性(マ ージン)を見込める。

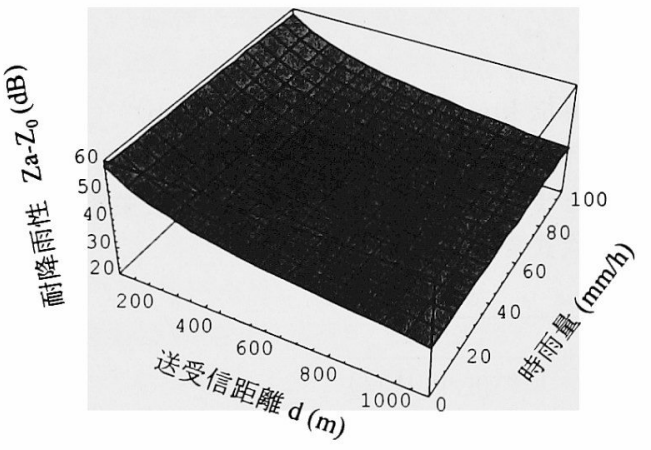

図 12 送受信系の耐降雨性

Fig.12. Margin of rain attenuation

\section{4 むすび}

本稿ではまず，鉄道沿線における通信トラフィックの 増大に対処するために, 列車無線通信システムのキャリ ア周波数として従来の U H F 帯に代えて, マイクロ波帯 を採用した際のシステム構成の提案を行った。沿線基地 局列車間の無線通信には, 広帯域幅の確保, 基地局数 の抑制, 設置の容易性の観点から $25 \mathrm{GHz}$ を採用する。

次に在来線沿線環境におけるマイクロ波伝搬特性の理 論的な取扱いについて明らかにした。解析方法として 2 波干渉に基づく方法, 簡易レイトレーシングにより複数 波干涉を考慮する方法, レイトレーシングにより多波干 涉を考慮する方法に対応した鉄道沿線環境の分類手法を 提案した。分類にあたり, 駅舎等の各種構造物が存在す
る駅構内と駅中間とに分け，駅中間を更に沿線環境の複 雑性より開放地 直線区間，側壁 高架区間，市街地 山間区間の三種類に細分し電化設備の有無を考慮の上, 解析方法を選択する。

次に駅中間における三種類のモデルについて，相対受 信レベルに関する伝搬特性を算定した。開放地 直線区 間では 2 波干涉に基づく周期的なレベルの落ち込みが観 測され，側壁 高架区間では底面および側壁反射波の複 数波干涉による急激なレベル変動が見られた。市街地 山間区間では立体交差による局所的なレベル変動が観測 された。計算結果は各モデルについて定性的に妥当な値 が得られたことから，沿線環境の分類方法および解析方 法が適正であることを示している。但し他の具体的な環 境, すなわち駅構内と電化設備を考慮した駅中間の環境 に対しても定性的に妥当な受信レベル変動が観測される かについては更なる検討を要する。また，実データでの 検証も今後の課題である。

降雨減衰特性に関しては, サービスエリア端において 影響は深刻となる。時雨量 $90 \mathrm{~mm} / \mathrm{hour}, 25 \mathrm{GHz}$ の場合 $1 \mathrm{~km}$ 先では晴天時より $13.2 \mathrm{~dB}$ の減衰が生じる。

本稿の計算では沿線構造物の影響を主に考慮したが, 送受信アンテナや車両形状, 反射体物性值, 偏波型式, キャリア周波数を変えた際の計算もある程度可能である ので，実際のシステム設計時には，より詳細な事前検討 に適用可能である。

最後に，本研究では東日本旅客鉄道(株)のご支援を賜 ることができた。心より謝意を表する次第である。

(平成 11 年 9 月 6 日受付, 平成 11 年 12 月 20 日再受付)

\section{文献}

(1) M.Uhlirz:"Concept of a GSM-based Communication System for High-Speed Trains”,Proc. 44 IEEE Vehicular Technology Conf., Stockholm, Sweden, pp.1130-1134 (1994-6)

(2) W.I.Way:"Subcarrier Multiplexed Lightwave Sys tems Design Consideration for Subcarrier Loop Application", J.Lightwave Technol., Vol.LT-7, No.11, pp.1806-1818 (1989-11)

（3）阿部紘士，石渡厚：「サブキャリア多重 光伝送方 式を用いた対列車ミリ波通信システムの検討」電学 論 C,Vol.117·C,No.9,pp 1308・1316 (1997-9)

(4) T.Hattori, K.Abe, K.Abe:"Analyses of Propagation Characteristics in Future Railway Communication Systems using 25GHz Band Radio", Proc. 49th IEEE Annual Vehicular Technology Conf. (1999-5)

(5) CCIR:"Future public land mobile telecommunication system", Report 1153(SG8) and Recom· mendation 687 . 
(6) William C.Y.Lee:"Mobile Communications Engineering”,McGraw-Hill Telecommunications(1982)

(7) Hiroshi Yamamura and Shin Sasaki, "Millimeter Wave Propagation Model and Delay Spread along the Maglev Guideway", IEICE Transactions on Communications, pp.1204-1207 (1995-8)

（8）今井哲朗，藤井輝也：「レイトレースを用いたスト リートマイクロセル伝搬推定システム」, 信学技報, RCS96-168 (1997-2)

（9）進士昌明：「無線通信の電波伝搬」，第 4 章，電子情 報通信学会 $(1992 \cdot 2)$

(10)桑原守ニ:「ディジタルマイクロ波通信」, 第 5 章, 企画センター（1984-5）

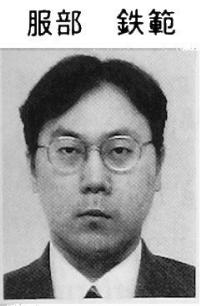

（正員） 1970 年 3 月 8 日生。94 年早稲 田大学大学院修士課程修了。同年東日本 旅客鉄道(株)入社。信号通信業務に従事。 97 年東北大学工学研究科電気・通信工学 専攻編入学。鉄道通信システムに関する 研究に従事。電子情報通信学会会員。

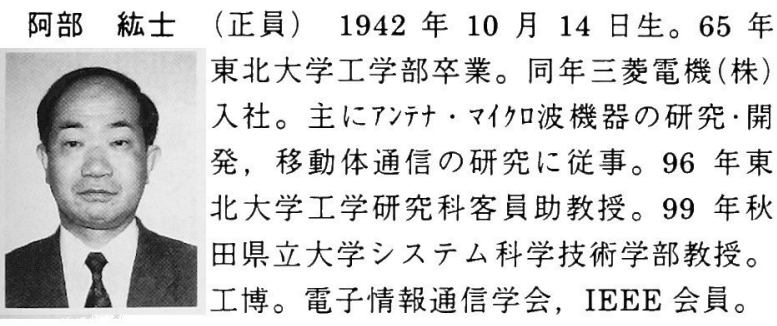

塩川孝泰（正員） 1944 年 12 月 25 日生。 73 年東

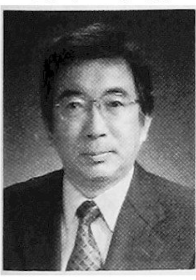
北大学大学院博士課程修了。同年国際電 信電話(株)入社。アンテナ,伝搬,干渉抑圧 等の研究に従事。97 年東北大学教授。 工博。97 年 $\sim 99$ 年電子情報通信学会通

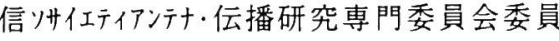
長。電子情報通信学会, IEEE 会員。

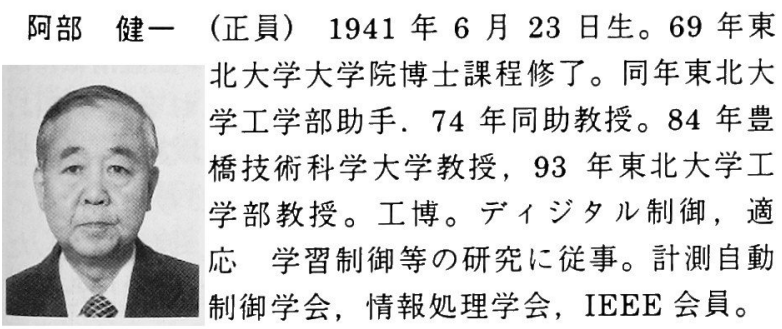

